\title{
Differentiating simple and composite tectonic landscapes using numerical fault slip modeling with an example from the south central Alborz Mountains, Iran
}

\author{
A. Landgraf, ${ }^{1}$ O. Zielke, ${ }^{2}$ J. R. Arrowsmith, ${ }^{3}$ P. Ballato, ${ }^{1}$ M. R. Strecker, ${ }^{1}$ \\ T. F. Schildgen, ${ }^{1}$ A. M. Friedrich, ${ }^{4}$ and S. H. Tabatabaei ${ }^{5}$ \\ Received 7 May 2012; revised 8 July 2013; accepted 9 July 2013; published 12 September 2013.
}

[1] The tectonically driven growth of mountains reflects the characteristics of the underlying fault systems and the applied tectonic forces. Over time, fault networks might be relatively static, but stress conditions could change and result in variations in fault slip orientation. Such a tectonic landscape would transition from a "simple" to a "composite" state: the topography of simple landscapes is correlated with a single set of tectonic boundary conditions, while composite landscapes contain inherited topography due to earlier deformation under different boundary conditions. We use fault interaction modeling to compare vertical displacement fields with topographic metrics to differentiate the two types of landscapes. By successively rotating the axis of maximum horizontal stress, we produce a suite of vertical displacement fields for comparison with real landscapes. We apply this model to a transpressional duplex in the south central Alborz Mountains of Iran, where NW oriented compression was superseded by neotectonic NE compression. The consistency between the modeled displacement field and real landforms indicates that the duplex topography is mostly compatible with the modern boundary conditions, but might include a small remnant from the earlier deformation phase. Our approach is applicable for various tectonic settings and represents an approach to identify the changing boundary conditions that produce composite landscapes. It may be particularly useful for identifying changes that occurred in regions where river profiles may no longer record a signal of the change or where the spatial pattern of uplift is complex.

Citation: Landgraf, A., O. Zielke, J. R. Arrowsmith, P. Ballato, M. R. Strecker, T. F. Schildgen, A. M. Friedrich, and S. H. Tabatabaei (2013), Differentiating simple and composite tectonic landscapes using numerical fault slip modeling with an example from the south central Alborz Mountains, Iran, J. Geophys. Res. Earth Surf., 118, 1792-1805, doi:10.1002/jgrf.20109.

\section{Introduction}

[2] The interplay between crustal deformation and surface processes, influenced by climate, has long been accepted to build and shape topography [see, e.g., Merritts and Ellis, 1994, and references therein]. From a simplified tectonic

\footnotetext{
Additional supporting information may be found in the online version of this article.

${ }^{1}$ Institut für Erd- und Umweltwissenschaften, Universität Potsdam, Potsdam, Germany.

${ }^{2}$ Physical Sciences and Engineering Division, King Abdullah University of Science and Technology, Thuwal, Saudi Arabia.

${ }^{3}$ School of Earth and Space Exploration, Arizona State University, Tempe, Arizona, USA.

${ }^{4}$ Department für Geo- und Umweltwissenschaften, Universität München, Munich, Germany.

${ }^{5}$ Building and Housing Research Center, Tehran, Iran.

Corresponding author: A. Landgraf, Institut für Erd- und Umweltwissenschaften, Universität Potsdam, Haus 60, Am Mühlenberg 3, DE-14476 Potsdam, Germany. (landgraf@geo.uni-potsdam.de)

(C2013. American Geophysical Union. All Rights Reserved. 2169-9003/13/10.1002/jgrf.20109
}

viewpoint, the evolution of fault-controlled topography in tectonically active regions is driven by repeated slip during earthquake ruptures [e.g., King et al., 1988; Stein et al., 1988; Bilham and King, 1989; Taboada et al., 1993; Hetzel et al., 2004; Meigs et al., 2008]. Fault scaling laws then suggest a systematic relationship between the amount and along-strike distribution of displacement for a given fault length, such that over time, the topography of a landform (mountain, ridge, basin) might reflect the slip distribution along the responsible faults [e.g., Scholz, 1982; Cowie et al., 1993; Dawers et al., 1993; Dawers and Anders, 1995; Ellis and Dunlap, 1988], and systematic changes of topography along strike can be expected [e.g., Taboada et al., 1993; Hetzel et al., 2004; Densmore et al., 2005].

[3] The long-term deformation field and topographic expression of protracted faulting are further influenced by the 3-D geometry of the responsible faults and their interactions [e.g., Bilham and King, 1989], resulting in superposition of single-fault displacement fields [e.g., Cowie et al., 1993; Dawers et al., 1993; Cowie et al., 2000; Walsh et al., 2002; Manighetti et al., 2009]. Thus, it is important to 
consider fault growth and interaction when assessing tectonic landforms, particularly if such landforms are being used to characterize the degree of tectonic activity of a region [e.g., Stein et al., 1997; Cooke and Kameda, 2002; Anderson et al., 2003; Lin and Stein, 2004].

[4] Following the simplifications above that tectonically driven growth of topography reflects the characteristics of slip along the underlying fault systems, the topography of small (kilometer-scale) geological structures might be approximated by repeated coseismic deformation along one or a population of interacting faults [e.g., Taboada et al., 1993], which can be modeled using simple elastic dislocation models [Okada, 1992]. The full earthquake cycle, however, includes interseismic motions when stresses are relaxed at depth and isostatic equilibrium is restored with buoyancy that partly counteracts the seismic deformation [e.g., King et al., 1988]. Together with loading and unloading due to sedimentation and erosion, interseismic processes must be considered when assessing the growth of larger geological structures.

[5] Uplift patterns and topography have been used successfully to infer the geometry of the responsible interacting faults, even in complex structural settings with different fault geometries and sense of slip [e.g., Taboada et al., 1993; Meigs et al., 2008]. Faults in tectonically active regions, however, also often represent weak, long-lived crustal discontinuities that reflect both present and past tectonic conditions. Faults may become reactivated under a wide range of stress states and orientations, and the landforms associated with their activity may thus not simply reflect fault motion driven by the current ambient crustal stresses. Instead, inherited topography generated under different (earlier) tectonic conditions might exist. How long such inherited topography persists will depend on the landscape response time. Because tectonic landforms are often used to characterize tectonic activity, inherited elements make assessments of modern stress conditions and tectonic displacements difficult. Several studies have noted that reactivation of inherited structures under changing boundary conditions can have important impacts on landscape response. In the northwestern Argentine Andes, for instance, Strecker and Marrett [1999] performed a fault kinematic study and showed that transfer faults between thrusts, which originally constituted local subdued topography, guided the course of antecedent rivers. After a regional rotation of the shortening direction [Marrett et al., 1994], however, such transfer areas experienced uplift. In the same region, along the eastern margin of the Puna plateau, inherited structures related to a Cretaceous rift appear to have been reactivated in Cenozoic times to accommodate uplift of discrete crustal blocks, forming the broken foreland morphology that contrasts markedly with the fold-thrust belt to the north in Bolivia [e.g., Grier et al., 1991; Hongn et al., 2007].

[6] This intriguing possibility of relating inherited landscape remnants to changing tectonic conditions constitutes the basis for our investigation of simple and composite tectonic landscapes. We define "simple" landscapes as those that develop during sustained tectonic boundary conditions acting on established or incipient faults. Changes in the far-field tectonic stress, however, alter the principle stress orientations, which can generate new faults and associated landforms, and also may reactivate or change the sense of slip on preexisting faults. The "composite" landscapes that consequently form will contain topography inherited from previous conditions. Some portion of the topography will be inconsistent with the regional present-day stress field and fault geometry. We distinguish "simple" and "composite" landscapes from the well-established geomorphic "steady state" versus "transient" landscapes [e.g., Burbank and Pinter, 1999; Whipple and Tucker, 1999; Whipple, 2001; Willett and Brandon, 2002; Gasparini et al., 2007; Whittaker, 2012] mostly by the underlying tectonic model. A simple landscape is correlated with a single (current) set of tectonic boundary conditions. It can be either steady state or transient. Transience can be climatically or tectonically controlled [e.g., Whittaker, 2012]. Hence, a tectonically transient landscape is also a simple landscape when a change in the rate but not the geometry of the tectonic boundary conditions has occurred. Composite landscapes, however, can only be transient. They contain remnants of inherited topography together with topography that is associated with modern boundary conditions. Differentiating between simple and composite landscapes is thus a major challenge in any attempt to understand long-term fault histories and their influence on landscape evolution.

[7] To explore composite and simple landscapes, we employ numerical fault interaction modeling (elastic dislocation modeling, here called Fault Interaction Modeling, FIMoz [Zielke and Arrowsmith, 2006; Zielke, 2009]) of freely slipping faults driven by incrementally changing horizontal stress directions $\left(S_{H} \max \right)$. We compute coseismic surface displacement fields for each tectonic scenario that can then be compared with topographic metrics. A simple landscape is consistent with a single vertical displacement field, whereas a composite landscape will include landscape elements that coincide with the modeled results of more than one displacement field. Thus, our model determines uplift/subsidence patterns in response to applied tectonic forcing, but without surface processes or feedbacks to isostatic adjustment or viscoelastic relaxation that may overprint the tectonically driven topographic signal [e.g., King et al., 1988; Stein et al., 1988; Taboada et al., 1993]. Although these processes reshape the resulting structure and might represent serious caveats, studies from different tectonic environments have shown that elastic dislocation models are well established and can be used for firstorder representations of the long-term displacement field and tentative comparison with a synthetic or real landscape [e.g., Stein et al., 1988; Anderson and Menking, 1995; Densmore et al., 1998; Ellis and Densmore, 2006]. We shall note here that our approach is simplified and mostly qualitative, and that despite the possible conflicts that might arise from the decoupling of tectonics from other landscapeshaping processes, we consider the vertical coseismic displacement pattern alone to be sufficient for a first-order comparison with real landscapes.

[8] To inform our synthetic explorations of simple and composite landscapes, we have chosen the south central Alborz Mountains of northern Iran (Figure 1) as a test site. Fault kinematic analysis of major and minor faults in this area has revealed early NW directed compression associated with dextral oblique thrusting. This deformation phase was superseded by NE oriented compression, which caused thrusting, sinistral strike-slip faulting, and fault reactivation 


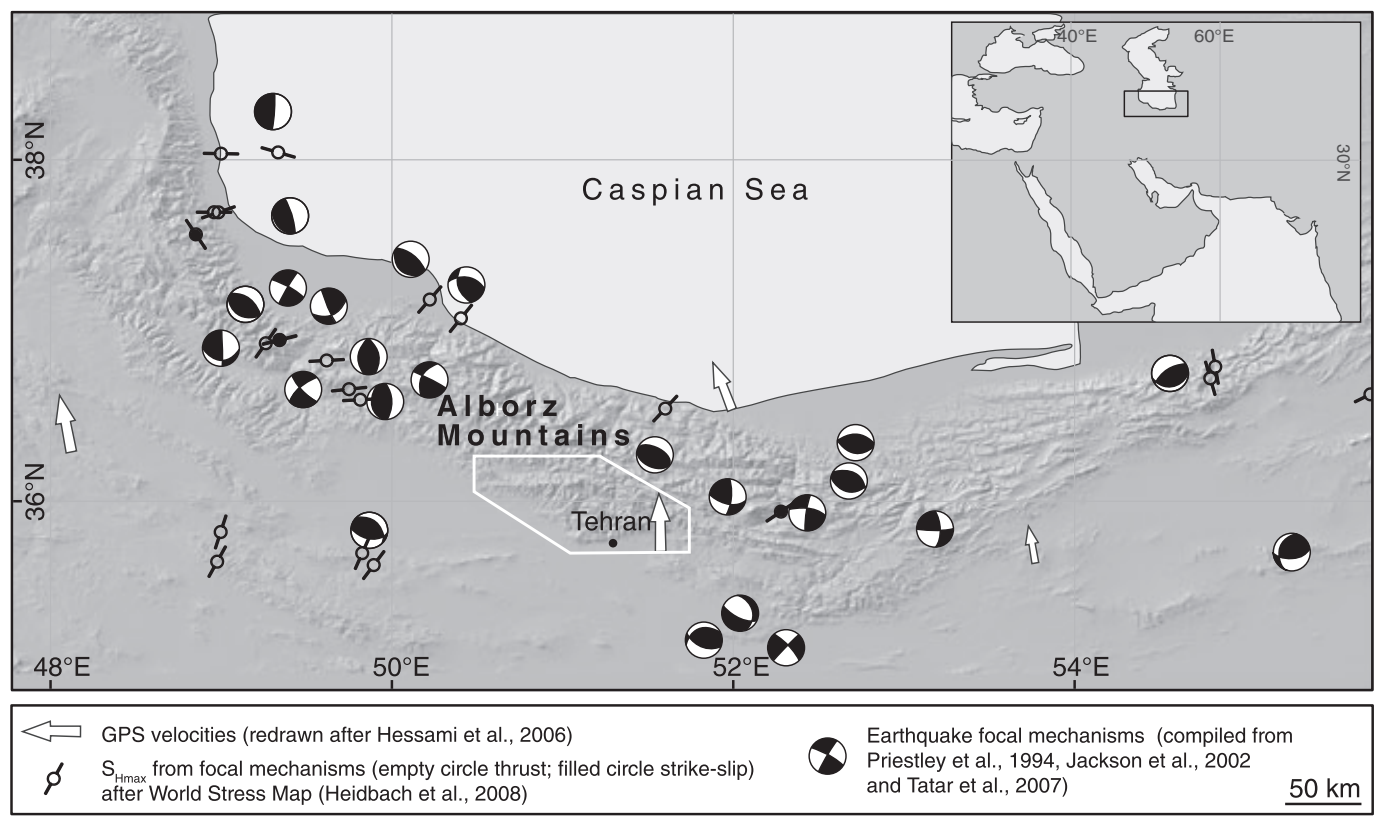

Figure 1. Overview of Alborz Mountains. SRTM hillshade model with compilations of $S_{H}$ max directions, GPS motion, and earthquake focal mechanisms. Box denotes study area. GPS-derived senses of relative motion (1999-2001) are relative to stable Eurasia [Hessami and Jamali, 2006]; note the variation in $S_{H}$ max direction [Heidbach et al., 2008] in different parts of the mountain belt. White polygon shows location of Figure 4.

[e.g., Allen et al., 2003; Guest et al., 2006a, 2006b; Landgraf et al., 2009; Allen et al., 2011]. The area represents a promising location to use the modern topography, fault geometry, and constraints on the tectonic history to test how tectonic forcing may have influenced landscape evolution.

[9] In this paper, we first model simple faulting scenarios to show the impact of a changing orientation of $S_{H} \max$ on the vertical (coseismic) displacement field. We then discuss landscape metrics for comparison with the modeling results. Finally, we compare the model results with local relief and elevation calculated from a digital elevation model (DEM) based on Shuttle Radar Topography Mission (SRTM) data of the Alborz Mountains. Those real landscape elements that are not reproduced by the modeling using present-day boundary conditions are expected to represent topography inherited from previous different boundary conditions. Finally, we discuss agreements and differences of the results with respect to the viability of boundary conditions in the south central Alborz Mountains and summarize the potential benefits of applying this approach to other study areas.

\section{Model Characteristics and Assumptions}

[10] To compute the vertical displacement field from sustained mechanical interaction and remote loading of faults, we have used 3-D numerical boundary element (BE) modeling [e.g., Kirkup, 1998]. This is a standard approach for the computation of displacement, strain, and stress fields in a homogeneous elastic half-space resulting from displacement discontinuities along arbitrarily oriented and sized rectangular faults [e.g., Okada, 1992; Taboada et al., 1993; Densmore et al., 1998; Ellis and Densmore, 2006;
Toda et al., 2011]. The BE code we apply is embedded in a MATLAB-based graphical user interface (GUI)-FIMoz [Zielke and Arrowsmith, 2006; Zielke, 2009]. In our study, a stress tensor that we assume to be representative of the regional stress field at a given time (i.e., during different deformation phases) is resolved onto each fault patch of our specified fault array to determine the applied normal and shear tractions. Shear stresses are released via in-plane slip. The fault patches are thus allowed to slip freely in response to the applied shear stress. Each fault in the array is broken into $2 \times 2 \mathrm{~km}$ patches (for tests on different patch sizes, see Figure $\mathrm{S} 1$ in the supporting information) which are also displaced normal to the fault plane and rotated to simulate the larger-scale roughness of natural faults [e.g., Power and Tullis, 1991; Renard et al., 2006; Sagy et al., 2007; Zielke and Arrowsmith, 2007; Zielke, 2009] (Figure 2). As for natural faults, slip along modeled fault patches changes the state of stress in the surrounding medium and therefore induces additional shear stress on all other fault patches. Those additional shear stresses are in turn released via in-plane slip.

[11] The frictionless model works iteratively, relaxing the resolved shear stresses until they fall below a threshold of $0.001 \mathrm{MPa}$ along each fault patch. When the interaction is complete, the slip at each patch is used to calculate the displacement field on the free surface of the half-space. Vertical displacement is used as a proxy for topographic development. For this study, we compute a vertical surface displacement field for each set of different boundary conditions. Assuming that elevated stresses due to the slip become permanent, the vertical displacement of the model should correspond to areas of fault-driven rock uplift and subsidence in real landscapes. 


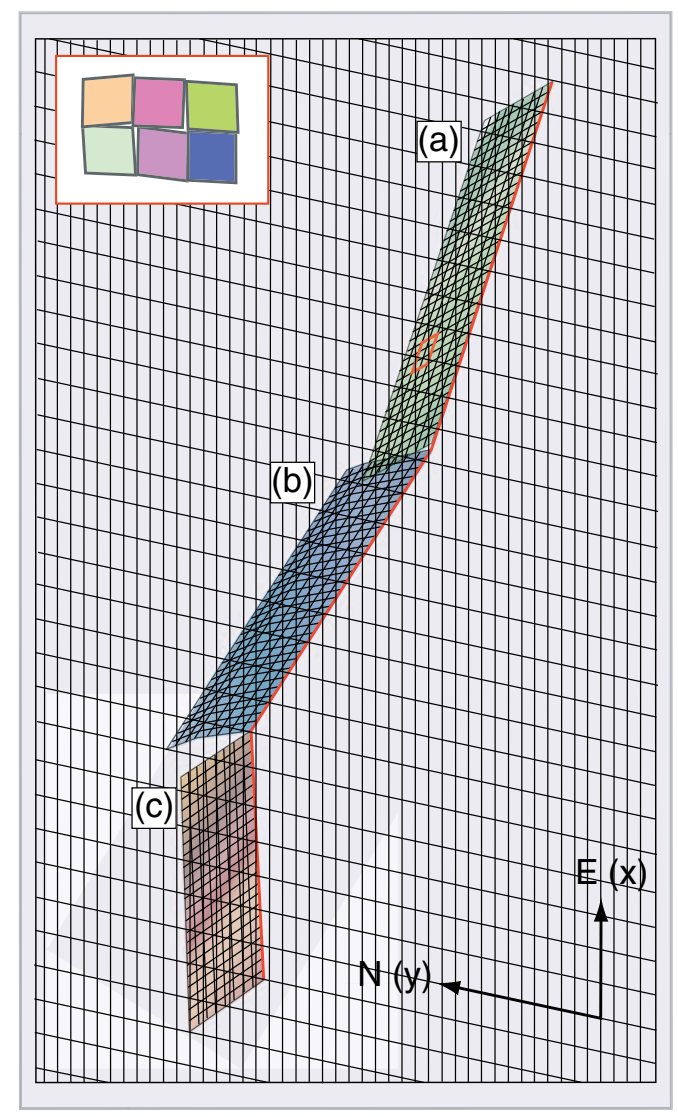

Figure 2. Conceptual figure to illustrate the fault geometry in the model. Rectangular faults are subdivided into segments $(\mathrm{a}-\mathrm{c})$ that are further subdivided into patches of equal size. The red line represents the intersection of the fault with the surface. Roughness was imposed on all faults, as shown in the inset (representative to red rectangle in segment (a)). The horizontal observation plane (gray with grid) is located at the surface. Note the changing downward connectivity between adjacent fault segments.

\section{Illustrations of Fault Interaction Modeling}

[12] To illustrate that the sensitivity of our modeling arises from the complexity of fault geometries relative to the applied stresses, we first discuss the modeling effects on simplified fault arrays. This produces a good understanding of the parameters that control uplift patterns in selected faulting scenarios (additional examples of the effects of changing differential stresses on step over geometry and double bending faults can be found in Figures S2 and S3 in the supporting information). These simple models build on the study of Bilham and King [1989], but explicitly introduce the effects of different maximum horizontal stress $\left(S_{H} \max \right)$ directions along predefined faults.

[13] Figure 3 provides a map view of the vertical displacement field. Analogous to the inferred evolution of $S_{H} \max$ in the Alborz Mountains of Iran [Landgraf et al., 2009], the faults are loaded by a regional stress tensor where $S_{H} \max$ (relative magnitude of 1) is compressional, but changes orientation from NW to N to NE. The vertical $\left(S_{v}\right)$ and least horizontal $\left(S_{h \text { min }}\right)$ stresses are equal in relative mag- nitude (0.2), which is compatible with a transpressional environment.

[14] Figure 3a represents a scenario with an E-W striking vertical fault. The antisymmetric uplift pattern (flipped and reflected across the fault) in response to oblique loading (which promotes strike-slip faulting) is controlled by the finite fault length. In contrast, when this fault dips $70^{\circ}$ to the north, it acts as a ramp, which promotes oblique thrusting (Figure 3b). If a model contains more than one fault, or segments with different geometry, such differences are even more pronounced. In two left-stepping, vertical fault segments, NW oriented compression causes uplift in the overlap, whereas NE oriented compression results in subsidence between the segments, such as in pull-apart basins (Figure 3c).

[15] The displacement pattern in a nonvertical step over is different and less sensitive to changes in the $S_{H}$ max direction (Figure 3d). Evenly distributed uplift along strike dominates and all chosen $S_{H}$ max directions produce uplift in the segment overlap. Under NE directed compression, however, the total amount of uplift is distributed slightly differently and a sharp change to subsidence occurs at the eastern end of the overlap. Finally, Figure $3 \mathrm{e}$ represents a fault with two bends, composed of two $70^{\circ}$ north dipping segments, linked by a $70^{\circ} \mathrm{NE}$ dipping segment. The maximum uplift is located at the concave or "inside corner" ("inside corner" after Cowgill et al. [2004]). This geometry is most favorably oriented to accommodate $\mathrm{N}$ or NE directed compression (and the resulting displacement is highest), whereas under NW compression, the geometry is ineffective at producing uplift or subsidence. In addition, the northward dip of the fault segments amplifies uplift in the northeastern corner, whereas the antisymmetric southeastern corner subsides (with a lower relative amount). Compared to the other scenarios we explored, this type of linked fault geometry is most sensitive to changes in the direction of $S_{H}$ max.

\section{Identifying Composite Landscapes}

[16] In tectonically active landscapes, areas of high rock uplift rate may be indicated by topographic metrics. In areas with relatively uniform bedrock erosivity and erosional processes, a strong correlation exists between river steepness (channel slope normalized by upstream drainage area) and rock uplift rate [e.g., Whipple et al., 1999; Wobus et al., 2006]. However, the steepness is sensitive to other factors, such as large landslides or dams. DiBiase et al. [2010] and Yildirim et al. [2011] have shown that local relief calculated from the DEM using a large analysis-window size (e.g., a circular window of $2.5 \mathrm{~km}$ radius) also captures trunk channels and tracks linearly with steepness indices. The interplay between uplift and erosion, however, is influenced by differences in erodibility of the material (e.g., rock type variability) and climate, which might also account for differences in relief [e.g., Tucker and Slingerland, 1996; Whipple and Tucker, 1999; Whipple et al., 2000; Hilley et al., 2004]. These influences can be assessed independently, for instance, using a statistical comparison between lithologic classes and the relief (see Figure 4). If secondary influences on relief formation can be excluded, local relief should be an appropriate proxy for rock uplift rate patterns across a landscape. 


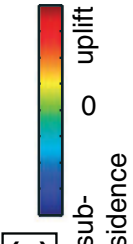

(a)
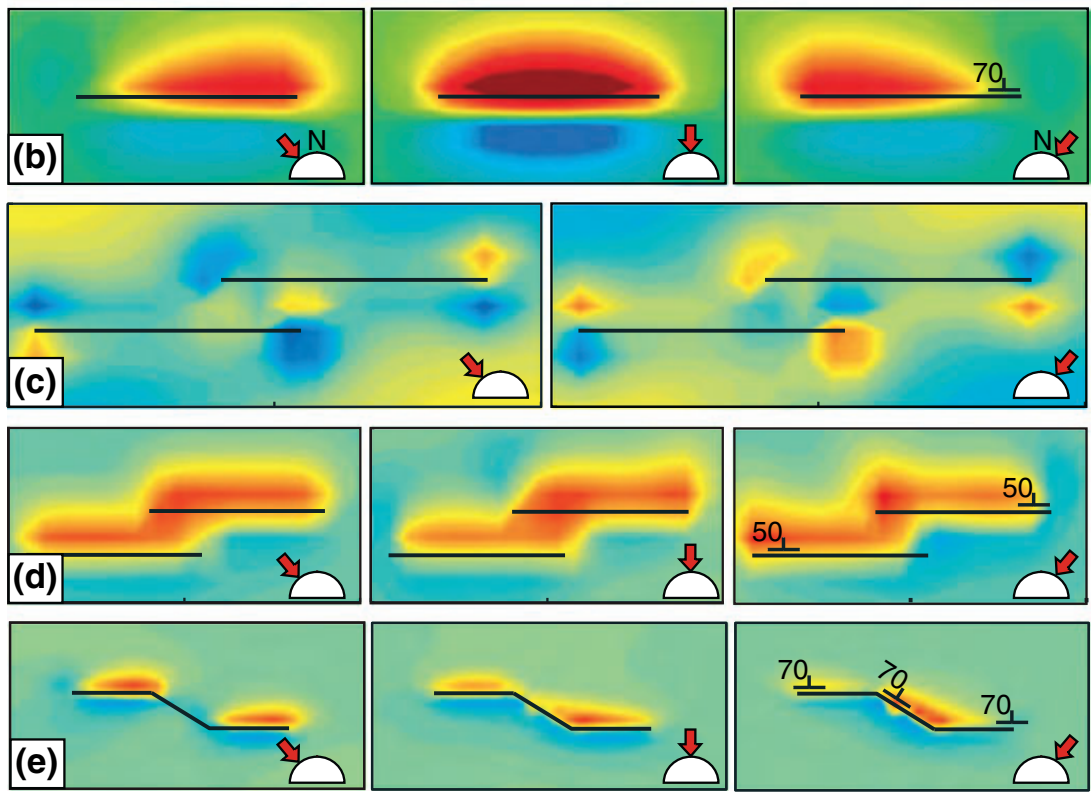

Figure 3. Map view of vertical displacement field of simplified fault arrays, calculated for a horizontal observation plane. Red arrows on semicircles indicate direction of applied $S_{H}$ max. In all panels, left figure is subjected to NW, right figure to NE, and middle figure to $\mathrm{N}$ directed compression with relative magnitudes of 1 for $S_{H}$ max and 0.2 for both $S_{v}$ and $S_{h \min }$, respectively. Positive displacement values (red) correspond to uplift and negative values (blue) are subsidence. For nonvertical faults, orientation is marked by attitude symbols in the right figures. (a) E-W striking, vertical strike-slip faults; antisymmetric uplift pattern is controlled by fault length. (b) E-W striking thrust and oblique slip faults. (c) Vertical leftstepping step over. (d) Left-stepping, inclined fault segments. (e) Double bending fault, constituted by three north and northeast dipping segments.

[17] Based on these inferences, a comparison between the relief map and the vertical displacement field derived from the fault interaction model should reveal whether or not present-day boundary conditions are consistent with the modern distribution of topography (for tests on other topographic metrics, see Figure S4 in the supporting information). For a simple landscape, we expect a good agreement with the model run under modern boundary conditions. The elevations of the real topography and modeled displacements may also be broadly consistent if mountain building is the result of a single direction of $S_{H} \max$. In a composite landscape, however, we expect that the agreement between modeled displacement fields and relief will decrease and so must be compared with fault interaction models that are derived from alternative stress states.

[18] Inherited topography should constitute those elements that cannot be explained by the tectonic conditions that determine a simple landscape under either transient or steady state conditions. Such regions can be recognized where high-elevation (and possibly high-relief) areas coincide with high vertical displacement established during previous boundary conditions.
[19] In our application to the Alborz Mountains, we compare elevation and local relief (based on analysis of $90 \mathrm{~m}$ resolution SRTM data measured over a circular window with $2.5 \mathrm{~km}$ radius) to the vertical displacement fields computed from the fault interaction modeling, which we initially set to $2000 \mathrm{~m}$ resolution to enable faster computations while maintaining reasonable resolution. We resampled all data sets to a common resolution of $1000 \mathrm{~m}$ and applied a low-pass filter via a 2 -D moving average window of $7 \times 7$ pixels. Thus, the DEM represents averaged elevation at $7000 \mathrm{~m}$ wavelength. For ease of comparison, we normalized the grids by dividing by their maximum values. Because the models show not only uplift but also subsidence, and therefore negative values, we have introduced two cases for normalization and discussion. Case 1 still contains relative subsidence. We subtracted the minimum value from all pixels, so all displacements are positive and then normalized. In case 2 , we ignored subsidence and only compared the uplift component by setting all negative values to zero prior to the normalization. In case 2 , we divided the rasters not by their respective but by the absolute maximum vertical displacement, derived from all 36 models. This eased the comparison of the net rock 

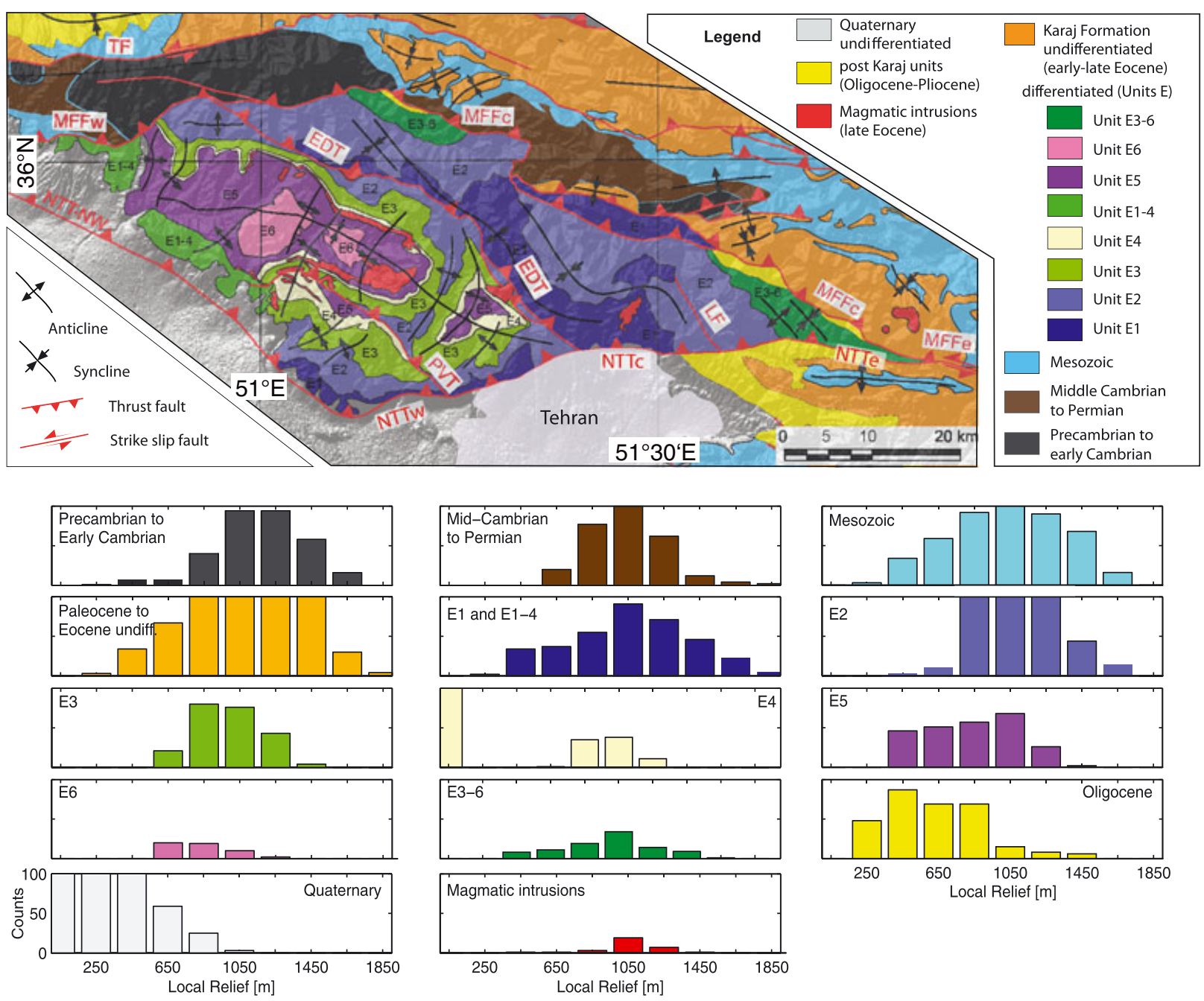

Figure 4. (top) Geologic map of the North Tehran Thrust Transpressional Duplex overlain on SRTM hillshade model. The geology is modified after geological maps of Tehran [Amini and Emami, 1993; Vahdati, 1997; Guest et al., 2006a]. Abbreviations: MFF, Mosha Fasham Fault (w, western; c, central; e, eastern segments); TF, Taleghan Fault; NTT, North Tehran Thrust (w, western; c, central; e, eastern segments); NTT-NW (NW striking frontal ramp); EDT, Emamzadeh-Davoud Thrust; PVT, Purkan-Vardij Thrust. Bar plots below show the frequency distribution of local relief (calculated using $2.5 \mathrm{~km}$ radius) within each mapped geological unit (or package of units, color coding same as above). Aside from the low relief of the Quaternary, most of the units have similar relief distributions, implying no significant rock-type control on the landscape development.

uplift along the fault array in each boundary setup (Figures 5 and 6).

[20] To assess model and topographic metric spatial correlation, we calculated the difference between the normalized vertical displacement and local relief. These differences were squared, so there is no discrimination between positive or negative differences. To better illustrate those areas that do not agree, we arbitrarily cut the values below the $30 \%$ fractile (Figure 6, middle column).

[21] To determine an overall measure of correlation between the model results (vertical displacement field) and the topographic metrics (local relief and elevation), we converted the grids into vectors, appending the first value of the following row to the last value of the previous row.
We then used bivariate analysis to understand the (pixel by pixel) relationship between the variables. We calculated Pearson's linear product-moment correlation coefficient, which is sensitive to various disturbances in the bivariate data set [e.g., Trauth, 2007]. A correlation coefficient of 1 represents a perfect linear correlation (an increase in modeled uplift with increasing local relief) whereas a coefficient of 0 suggests no correlation. A random-chance grid (by using mean and standard deviation of the local relief matrix and applying all filter techniques to it) yields a significantly smaller correlation coefficient (maximum 0.16; see Figure S5). Pearson's correlation coefficient does not distinguish spatial coincidence but rather describes the overall agreement between data sets (Figure 7). 

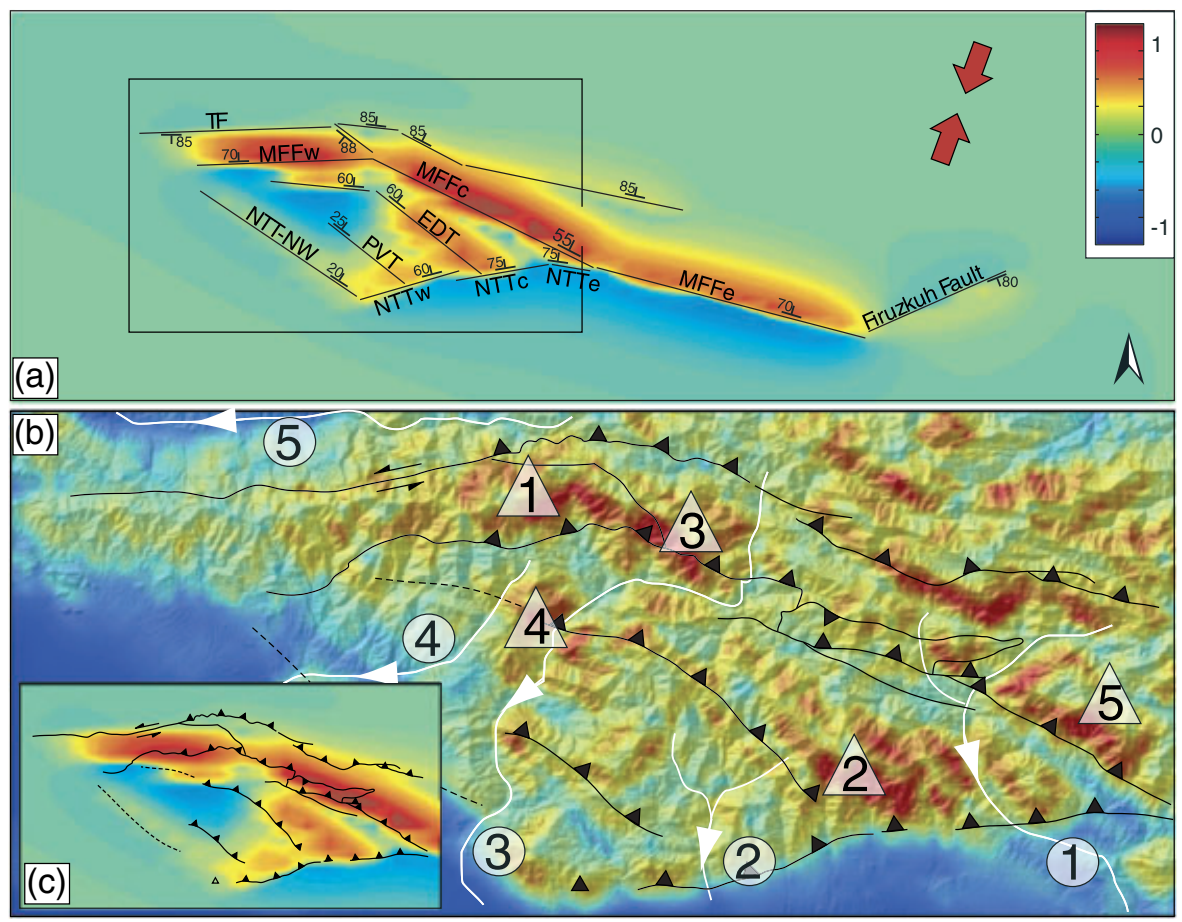

Figure 5. (a) Map view of simplified fault array with attitude symbols for strike and dip, for which interaction was calculated; colors show normalized displacement, as in Figure 3. Abbreviations of fault names as in Figure 4 (see Figure S6 for fault geometry data). Interaction was calculated using all displayed faults, but comparison is limited to the area inside the black frame. (b) Local relief map of central Alborz Mountains (stretched by standard deviation), superposed on SRTM-based hillshade. Window size is approximately $110 \times 55 \mathrm{~km}$. (c) Modeled data (same as Figure 5a, for comparison with Figure $5 \mathrm{~b}$ ). Figures $5 \mathrm{~b}$ and $5 \mathrm{c}$ show simplified faults after geological map of Tehran [Amini and Emami, 1993; Vahdati, 1997]. White triangles on elevation correspond to presumably high uplift rate areas, which are (1) Taleghan range with Mount Kuh-e-Kahar, (2) Mount Touchal, (3) Mount Bajdan, (4) Karaj River, and (5) Mount Varjin, respectively; circled numbers correspond to the rivers (1) Jajrud, (2) Kan, (3) Karaj, (4) Kordanrud, and (5) Taleghanrud.

\section{Application to the South Central Alborz Mountains, Iran}

\subsection{Tectonic Setting of the Study Area}

[22] The Alborz Mountains accommodate about $6 \pm$ $2 \mathrm{~mm} / \mathrm{a}$ of NNE directed shortening relative to a Eurasian reference frame, i.e., one fourth of the Arabian-Eurasian convergence in Iran [e.g., Priestley et al., 1994; Berberian and Yeats, 1999; Jackson et al., 2002; Vernant et al., 2004a, 2004b; Masson et al., 2007] (Figure 1). In addition to the NNE directed shortening component, range-wide left-lateral shearing at a rate of $4 \pm 2 \mathrm{~mm} / \mathrm{a}$ is observed, because the adjacent South Caspian basin moves NW relative to Eurasia [Vernant et al., 2004b]. The direction of maximum shortening in the study area is between $\mathrm{N} 20^{\circ} \mathrm{E}$ (based on the GPS velocity field [Masson et al., 2007]) and approximately $\mathrm{N} 45^{\circ} \mathrm{E}$ (based on stress inversions from focal mechanisms from the central Alborz Mountains [Heidbach et al., 2008]).

[23] The main faults investigated in this modeling study are the seismically active Mosha-Fasham and Taleghan faults (MFF and TF) and the North Tehran Thrust (NTT)(Figure 4). Historical seismicity data suggest events with magnitudes larger than 7 for this region [Ambraseys, 1974; Ambraseys and Melville, 1982; Berberian and Yeats, 1999, 2001], and there is ample evidence for pronounced
Quaternary activity [e.g., Landgraf et al., 2009; Ritz et al., 2012].

[24] Faults in the Alborz Mountains record a complicated kinematic history, often with reactivation under changing maximum horizontal stress directions [Allen et al., 2003; Ritz et al., 2006; Guest et al., 2006a, 2006b; Landgraf et al., 2009; Allen et al., 2011]. The earliest history of the MFF was dominated by normal faulting in the Late Triassic, followed by Tertiary contractile reactivation [Zanchi et al., 2006]. Fault kinematic analysis reveals early NW directed compression and dextral oblique thrusting. This episode of deformation was superseded by NE oriented compression, which caused thrusting and sinistral strike-slip faulting [Landgraf et al., 2009], resulting in fault reactivation and the formation of a nascent transpressional duplex adjacent to the city of Tehran [e.g., Guest et al., 2006a; Landgraf et al., 2009]. This duplex system transfers motion from the eastern sector of the Mosha-Fasham Fault toward its western branch and/or the parallel Taleghan fault branch. It incorporates four NW striking frontal ramps: the prolongation of the North Tehran Thrust (NTT-NW), the PurkanVardij Thrust (PVT), the Emamzadeh Davoud Thrust (EDT), and the central segment of the Mosha-Fasham Fault (Figure 4). These frontal ramps join the North Tehran Thrust [Landgraf et al., 2009]. 


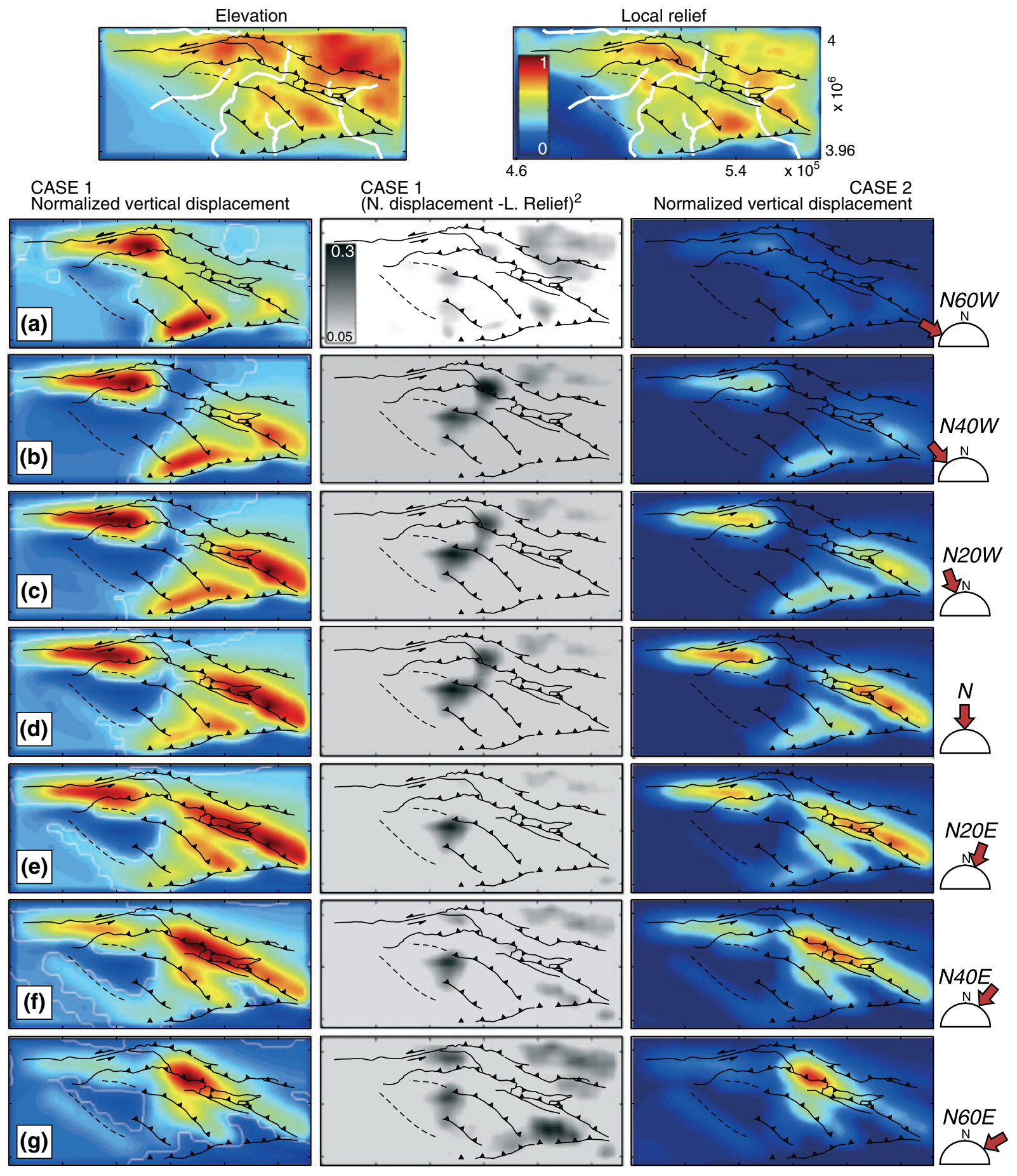

Figure 6. Normalized topographic metrics and vertical displacement fields; (top) normalized elevation, smoothed from (left) SRTM and (right) local relief. Normalized elevation and local relief maps are shown in the same color scheme as displacement. Normalized elevation compared to a real range of topography between 1333 and $4123 \mathrm{~m}$. Main rivers (white) and faults (black) are superposed for illustration. $X$ and $Y$ scales on relief map are in meters, corresponding to Universal Transverse Mercator Zone 39N. (a-g) Normalized vertical displacement fields for different compression directions with varying azimuthal steps of $20^{\circ}$. (left column) Case 1 has the position of the zero elevation contour in white. Values above it are uplifting. (middle column) Squared differences between local relief and modeled vertical displacement illustrate variability (case 1). (right column) Case 2 is normalized using the maximum value of all models and hence also illustrates the net amount of uplift with respect to each scenario. 


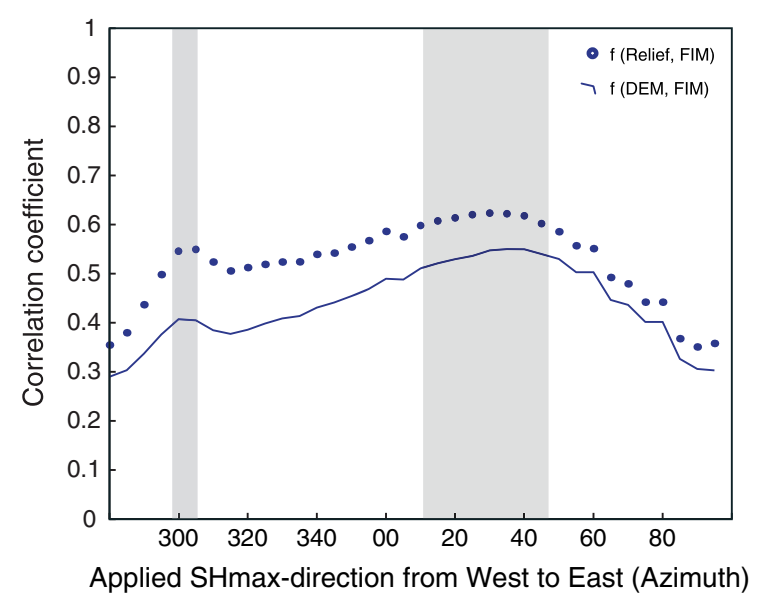

Figure 7. Pixel-wise derived Pearson's linear correlation coefficient between topographic metrics and vertical displacement field of the fault interaction models with varying $S_{H}$ max azimuth. Dots denote correlation coefficient between local relief and modeled displacement, whereas line shows coefficients between elevation and modeled displacement. Boxes depict best correlations between models and topographic metrics $\left(\mathrm{N} 50^{\circ} \mathrm{W}\right.$ to $\mathrm{N} 65^{\circ} \mathrm{W}$ and between $\mathrm{N} 15^{\circ} \mathrm{E}$ and $\left.\mathrm{N} 45^{\circ} \mathrm{E}\right)$.

[25] The timing of the changeover is still subject to discussion due to the scarcity of chronologic information. Crosscutting relationships (e.g., older dextral faults that are intruded by a $7 \mathrm{Ma}$ old pluton) document that it took place earlier than 8-7 Ma [e.g., Axen et al., 2001]. In any case, a change in the tectonic boundary conditions resulted in a change in fault kinematics, which in turn has influenced the growth of topography and landscape evolution.

[26] No subsurface information is available for the investigated faults, and the few earthquakes [Ashtari et al., 2005] are not sufficient to characterize the fault geometries at depth. To incorporate the faults into the model, we have used our own field measurements (strike and dip) and published geological cross sections [Guest et al., 2006a, 2006b], with additional information from Allen et al. [2003] and Zanchi et al. [2006] (see fault data table and Figure S6 in the supporting information). To avoid the topographic outlier of the $5671 \mathrm{~m}$-high Damavand volcano, which is located north of the seismically active Mosha-Fasham Fault, all data sets were cut to the areal extent of the relief map (Figures $5 \mathrm{~b}$ and 5c). Thus, we use this important fault in the interaction model (e.g., Figure 5a), but compare only the effects to the west of the volcano.

[27] The highest peak elevations in our study area are reached at Mount Kuh-e-Kahar, (Figure 5, area 1, $4347 \mathrm{~m}$ ) and Mount Touchal (Figure 5, area 2, $3962 \mathrm{~m}$ ). The local relief map exhibits a few distinct zones of high local relief (Figure 5, areas 1 to 5), e.g., the Taleghan range (especially Kuh-e-Kahar, area 1), Mount Touchal (area 2), and Mount Bajdan (area 3). A fourth high relief area (area 4) is located along the course of the Karaj River and a fifth high relief area (area 5), here informally called Mount Varjin, is located in the hanging wall of the central MFF segment, near the eastern border of the study area. We have calculated frequency distributions of local relief for every geological unit or package of units as mapped in the duplex (Figure 4) to see if high local relief correlates with rock units. Young, partly unconsolidated units (Quaternary, but also some Oligocene units) are associated with low local relief. The older units are within uncertainty indistinguishable from each other in their local relief distribution. Thus, we assume that local relief reflects the rock uplift rate pattern.

\subsection{Present-Day Boundary Conditions}

[28] Figures 5a and 5c show the vertical displacement of the model, driven by a regional stress tensor, calculated from the GPS-derived strain rate and direction [Masson et al., 2007] with a $\mathrm{N} 20^{\circ} \mathrm{E}$ directed $S_{H} \max$. Assuming that the shortening direction corresponds to the direction of maximum horizontal compression, this model represents the recent boundary conditions and therefore should highlight areas of active rock uplift. High vertical displacement is achieved between the western MFF segment and the Taleghan fault, along the entire central MFF segment, and at the concave intersection between the central NTT segment and the EDT (Mount Touchal). A smaller amount of displacement is distributed along the western NTT and EDT segments.

[29] There is considerable agreement between the vertical displacement field and the local relief (Figures 5 and 6e). However, while the vertical displacement is distributed along strike of the MFF, high local relief is focused around Mount Kuh-e-Kahar (see Figure 5, area 1), Mount Bajdan (area 3), and Mount Varjin (area 5). A significant spatial difference coincides with the subsiding area in the central western half of the fault array (Figure 6e).

\subsection{Applying Different Boundary Conditions}

[30] Considering the strong evidence that the central Alborz Mountains experienced a change in the maximum horizontal compression direction from an initial NW to a NNE direction [Landgraf et al., 2009], we modeled the surface displacement field for $S_{H}$ max directions from $\mathrm{W}$ to $\mathrm{E}$, respectively. The results are shown in Figure 6 with increments of $20^{\circ}$ (see results of $5^{\circ}$ increments in Figures S7-S10).

[31] WNW to NNW directed maximum horizontal compression favors high displacement along the western segments of MFF and NTT and in the eastern part of the central MFF segment. The amount and focus of high displacement shift between the scenarios (Figures 6a-6c). With $\mathrm{N}$ and NNE directed $S_{H} \max$, displacement becomes less accentuated at the western MFF, almost insignificant along the western NTT, but considerable at the central NTT, and more distributed along the central MFF. NE directed maximum horizontal compression favors high displacement almost explicitly around the eastern part of the central MFF segment. The areally most extensive displacement is generated under N- to NE-directed compression (Figures 6d-6f). These $S_{H}$ max directions also seem to promote higher absolute displacement (Figure 6, right). In the following, we describe the model results with respect to the areas outlined in Figure 5b, and we compare the modeled vertical displacement to the local relief and possible lithological characteristics for each region.

[32] The Taleghan range (Figure 5b, area 1) exhibits uplift in all model scenarios, except for dominantly ENE- 
WSW compression, but with a different amount and shifting focus of maximum displacements along the E-W strike. The western Taleghan and Mosha-Fasham faults are favorably oriented to accommodate NW to NE-directed compression (Figures 6a-6f). Furthermore, the opposing dip of the subvertical faults produces effective uplift of the range. This area is associated with outcrops of Precambrian to lower Cambrian units (see Figure 4), including dolomite, sandstone, quartzite, and limestone [Haghipour et al., 1987]. Despite the higher relief that is expected in these rock types in general, we do not see an especially higher frequency of high relief compared to the Mesozoic and Eocene units (see Figure 4). Furthermore, the exposure of these deep units implies that the area has experienced more exhumation compared to other parts of the duplex.

[33] Along the NTT, NW directed compression favors uplift along the western segment (Figures 6a-6d), which is less steep than the central and eastern segments $\left(60^{\circ}\right.$ versus $\left.75^{\circ}\right)$. Uplift along the central segment is greater in simulations where $S_{H} \max$ is oriented $\mathrm{N}$ to $\mathrm{NNE}$, whereby the EDT is incorporated as a frontal ramp (Figures 6d and 6e). In this case, Mount Touchal (Figure 5b, area 2) is located in the obtuse inside corner between these faults, which promotes rock uplift (compare Figure 3d). The NTT-PVT and NTT-NTT/NW corners, however, are less effective. The required range of orientations of compression to cause rock uplift of Mount Touchal is rather narrow. Subjected to $\mathrm{N} 40^{\circ} \mathrm{E}$ directed compression, the summit still experiences rock uplift, but the maximum uplift shifts toward NW. Mount Touchal comprises Eocene volcanoclastic units E1 and E2 in (Figure 4). In the immediate inside corner between NTT and EDT, the oldest and deepest section of the Eocene sequence (andesitic lava and pyroclastic deposits) is exposed. Exposure of these units and the intriguing finding that of all thrust sheets involved in the duplex, this is the only area where zircon (U-Th)/He ages are reset [Ballato et al., 2013], likewise indicate substantial rock uplift and exhumation. When moving toward the more distal frontal ramps in the SW of the duplex, zircon (U-Th)/He ages are only partially reset, indicating slower exhumation rates [Ballato et al., 2013].

[34] Maximum uplift at Mount Bajdan (Figure 5, area 3) is accomplished with $\mathrm{N} 45^{\circ} \mathrm{E}$ directed compression, but uplift is even more pronounced if the $S_{H} \max$ direction becomes more oblique with respect to the central MFF segment (Figures $6 \mathrm{f}-6 \mathrm{~g}$ ). This area is characterized by NE trending synclines and anticlines, exposing Mesozoic to Eocene strata (see Figure 4). As lithological control on relief can be excluded, tectonic uplift may be the reason for the observed high local relief. However, scenarios that favor uplift of Mount Bajdan cannot explain any other uplift in the duplex array and show several spots of deviation from the local relief map (Figure $6 \mathrm{~g}$, middle).

[35] None of our modeling results show significant vertical displacement associated with area 4 in Figure 5.

[36] The slight right bend of the MFF, near the eastern border of the study area is another concave inside corner (Figure 5, area 5). This area (the hanging wall of the MFF, the largest fault in our model setup) shows a local high at that location in simulations where $S_{H} \max$ is oriented NW to $\mathrm{N}$ (Figures 6b-6d).
[37] The fault model configurations also cause certain areas to subside (Figure 6, left column). NW directed compression leads to subsidence SW of the Taleghan range and to a lesser degree in the footwall of the central MFF segment. There are no associated large modern depocenters visible in the DEM, but locally extensive Pliocene to Quaternary deposits exist, which might have filled accommodation space (Figure 4). Incorporation of the frontal ramps under $\mathrm{N}$ to $\mathrm{NE}$ directed compression subsequently results in uplift of the MFF central footwall, in combination with a narrow piggyback basin. In addition, significant subsidence takes place south of the Taleghan range, slightly west of the center of the model. This region corresponds to areas of relatively low elevation and high local relief (Figure 5, area 4). Because areas that undergo subsidence have at least been partially filled, the comparison between modeled displacement fields in areas of subsidence and local relief may not be useful for testing the models.

\subsection{Correlation Between Model and Topographic Metrics}

[38] The correlation plot shows that elevation and relief generally agree, but the model results always correlate better with local relief than with elevation (Figure 7). The highest Pearson correlation coefficient between relief and the various vertical displacement fields is achieved with a $S_{H}$ max direction oriented between $\mathrm{N} 15^{\circ} \mathrm{E}$ and $\mathrm{N} 45^{\circ} \mathrm{E}$ : present-day conditions (Figure 7). Hence, an initial conclusion is that the topography of the Alborz is largely a simple landscape.

[39] Although correlation coefficients generally decrease as the orientations deviate from that range, a local peak in correlation coefficients also occurs at $\mathrm{N} 50^{\circ} \mathrm{W}$ to $\mathrm{N} 65^{\circ} \mathrm{W}$. The corresponding vertical displacement fields show that models obtained by those orientations best explain the high relief that occurs along the nearly E-W trending structures, most notably along the western end of the NTT, where less uplift is predicted under the modern boundary conditions. Good agreement also exists at the eastern Taleghan range, where the location of high peak elevation (Mount Kuh-e-Kahar) and high relief correspond to the maximum vertical displacement derived by models with these boundary conditions.

\section{Discussion}

\subsection{Implications for the Tectonic and Landscape Evolution of the South Central Alborz Mountains}

[40] In the south central Alborz Mountains, good agreement exists between model results representing the presentday boundary conditions and the relief characteristics derived from the DEM. We interpret this consistency between modeled results and the mountain-scale landforms as a good indicator for long-term fault interaction. Furthermore, the close agreement between the modeled displacement field and topographic metrics shows that despite some limitations, the dislocation modeling approach works well in this setting. More importantly, the results indicate that the landscape proxies for active tectonics can be largely explained by the present-day boundary conditions (i.e., the landscape is predominantly simple). However, the results show a relatively wide range of best correlating $S_{H} \max$ 
directions of approximately $30^{\circ}$. In a semiquantitative study like ours, this may reflect the resolution that is possible to obtain. A secondary peak in the Pearson correlation between $\mathrm{N} 55^{\circ} \mathrm{W}$ and $\mathrm{N} 60^{\circ} \mathrm{W}$ might be related to inherited topography generated under earlier tectonic boundary conditions (Figure 7), meaning that a small portion of the landscape could be composite. In general, we would expect such a peak in correlations to degrade over time, after the previous tectonic phase ceases and inherited topography starts to be removed. Reasonable candidates for inherited topography are the Mount Kuh-e-Kahar at the Taleghan range, and also Mount Varjin (Figure 5, areas 1 and 5).

[41] The high displacement in the Mount Touchal area, a concave inside corner position in the fault array, suggests that this fault configuration promotes rapid uplift (Figures 6d, 6e, and 3e). However, only the modern $\mathrm{N}$ to NNE directed $S_{H} \max$ directions can produce such pronounced uplift.

[42] Other areas are consistent with uplift driven by NW rather than NE directed compression. The existence of inherited topography in the Alborz Mountains is most likely along E-W striking faults. These faults are favorably oriented to accommodate rapid uplift under NW directed compression; however, they are also favorable to accommodate uplift under $\mathrm{N}$ directed and to a lesser extent NE directed compression (Figure 6). As a result, the overall magnitude of uplift along E-W striking faults compared to others in the region might be more diagnostic than the mere occurrence of uplift to reveal the kinematic changeover (Figures 6a-6e). The exposure of Paleozoic units in the hanging wall of those faults indicates that a substantial amount of rock uplift and exhumation has occurred, underscoring the importance of the MFF as long-lived fault with a high total displacement and protracted deformation history.

[43] For the evolution of the south central Alborz Mountains, our results indicate that the change over from dextral to sinistral transpression has renewed the topography and only limited remnants are preserved from the previous conditions. This is compatible with the results of zircon (U-Th)/He thermochronology that shows fast cooling associated with SW directed thrusting across the frontal ramps at about 18-14 and 9.5-7.5 Ma [Ballato et al., 2013] and a low-temperature thermochronology profile along the Karaj River [Guest et al., 2006b] that documents that the duplex region was tectonically active starting at about $7 \mathrm{Ma}$. The data suggest that about $2-3 \mathrm{~km}$ of crust has been removed in this part of the range. However, given the large degree of heterogeneity in exhumation patterns, reflected by other parts of the orogen that show unreset apatite (U-Th)/He ages [Ballato et al., 2013], inherited topography could have still been preserved in certain parts of the orogen.

\subsection{Composite Landscapes: Additional Examples}

[44] Fault interaction modeling can be extended to various tectonic settings to understand composite landscapes. The evolution of orogens or rifts is often accompanied by a changing stress state, and faults are long-lived and often reactivated structures [e.g., Golombek et al., 1983; Strecker et al., 1990; Bosworth and Strecker, 1997; Strecker and Marrett, 1999; Schumacher, 2002; Cortés et al., 2005; Mora et al., 2006]. Preexisting, inherited faults may thus influence later reactivation and the loci of deformation and uplift, as well as the width of the deformation zone [e.g., Marshak et al., 2000; Schumacher, 2002; Hilley et al., 2005; Mora et al., 2006]. In rift settings, for instance, it might be applicable to compare modeled subsidence with real basin fill, which helps differentiate "negative composite topography." Schumacher [2002] compared isopach maps of different temporal intervals with in situ measurements of inherited faults in the Upper Rhine Graben to show how rotations in the extension-direction shifted depositional centers and how inherited faults influenced rifting. Thus, the combination of landscape analysis and isopach maps can be used to compare depositional centers with modeled subsiding areas.

\subsection{Limitations of Tectonic Model}

[45] The approach we have presented is limited by the simple model setup. Transcurrent motion might cause translations of the landscape elements relative to the original faulting position over time and thus decrease the spatial comparability. Topographic advection through a restraining bend or pressure ridge, such as the Santa Cruz Mountains in a left-step restraining bend of the San Andreas Fault (SAF) in California, causes crust to thicken, deform, and be uplifted when it arrives at the bend and then degrade through erosion when it is transported away from the bend [Anderson, 1990, 1994]. At a finer spatial scale, topography along the Dragon's Back pressure ridge grows in response to progressive deformation along a geometric complexity at the San Andreas strike-slip fault. As expected for tectonically active mountains, basin relief increases during rock uplift, but interestingly, Hilley and Arrowsmith [2008] found that cessation of rock uplift is accompanied by an increase in channel concavity, as well as undercutting and failing hillslopes, which further increase the basin relief. Thus, the observed response times for channels here are in the order of thousands of years, while hillslopes might need an order of magnitude longer to adjust to changes in rock uplift rates [Hilley and Arrowsmith, 2008]. As we found in the Alborz Mountains, these studies from the SAF region show that present-day deformation patterns along such complexities can be assessed by comparisons with topographic metrics such as local relief, but response times are important.

[46] Reactivated faults constitute planes of weakness that may be active in nonoptimally oriented stress fields, leading to ambiguity in relating stress orientations and directions to fault orientation and motion [e.g., Scholz, 2002; Hilley et al., 2005]. In this study, we predefine the major fault system and apply the shear stress to frictionless faults for different stress-tensor orientations. One of the key assumptions is that fault orientation is stable over time. Crustal blocks may rotate between slipping faults over time. Rotating faults and blocks can result in a complex fault and uplift pattern that may be similar to structural features solely related to stress-field rotations. This type of process could result in a composite landscape, if previously uplifted blocks were rotated out of rapidly uplifting zones, requiring detailed structural observations to interpret the inherited topography. Although this may be important for some areas [e.g., Ron et al., 1993], it is not important for the south central Alborz Mountains [Landgraf et al., 2009]. Topographic loading and unloading might alter the tectonic stress field, causing migration to other faults and crustal anisotropies close to failure [e.g., Hilley et al., 2005] or it may induce a switch between a 
thrusting and strike-slip faulting regime [e.g., Cowgill et al., 2004]. These issues are not addressed by our modeling, but they have to be taken into account when interpreting results from complex areas.

\subsection{Landscape Response Time}

[47] Our argument to differentiate topography representing different stress states implies that a previous landscape signal remains in the topography. But how long can the inherited topography maintain its original characteristics? In places like the NW Argentine Andes and the Kenya Rift, topographic remnants of earlier tectonic regimes persist though changes in the stress state and associated kinematic regime that occurred on the order of hundreds of thousands to millions of years ago [e.g., Strecker et al., 1990; Schumacher, 2002]. In some parts of the world, occurrences of relict landscapes or fluvial hanging valleys argue for transient landscape signals that can be visible even after several millions of years [e.g., Crosby et al., 2007; Hoke et al., 2007; Schildgen et al., 2012]. On the scale of entire orogens, the time for topography to fully adjust to changes in tectonic and/or climatic forcing have been estimated to be on the order of 1 million years for Taiwan's Central Range, 1.5 million years for the Southern Alps of New Zealand, and about 5.5 million years in the Eastern Alps [Tomkin and Roe, 2007; Whipple, 2009]. Inherited topography in a composite landscape might only persist for a few million years. In the case of the Alborz Mountains, the change in the boundary conditions is long enough ago that we might not expect to preserve much of the inherited topography. However, how and how fast landscapes respond to a spatial change in the uplift pattern is not well understood, but the response could involve stream diversion or piracy, and changes in sediment routing. Inherited topography and lateral rheological variations partly control basin connectivity and synorogenic drainage changes [e.g., Garcia-Castellanos and Cloetingh, 2011], suggesting that some parts of the drainage system might persist, even if the actual topographic surface has lowered well below the original relief. This might very well be true for mountain peaks, for instance. Spotila [2012] found that mountain peaks that constitute divide junctions are related to the drainage basin structure, but are relatively stable in fluvial and glacial environments and might even work against the impulse of drainage divides to migrate. Thus, if such topographic elements were related to former tectonic boundary conditions and persist even after landscape reorganizations, our approach should be able to recognize them.

\section{Conclusions}

[48] Our study is based on the idea that tectonically active landscapes can be composite and may contain specific elements inherited from earlier evolution under different boundary conditions. Our application of fault interaction modeling to interpret topography in the Alborz Mountains shows that distinct zones of inferred high rock uplift rates are associated with slip along interacting faults in a duplex array. The E-W striking faults bounding the Taleghan range, an area of high elevation and relief, and hence inferred high uplift rate, are favorably oriented to undergo reactivation under compression directed anywhere from NW to NE.
Nonetheless, our approach still appears to differentiate the effects of NW directed shortening from NNE to NE directed shortening, allowing us to infer that although the topography can largely be explained by present-day boundary conditions, certain areas could contain topography inherited from the earlier deformation phase.

[49] The use of fault interaction modeling to help decipher different phases of deformation in composite landscapes can be extended to various tectonic settings and problems. Generally, our modeling revealed that geometric complexities (such as concave inside corners) between faults or segments are particularly indicative of specific boundary conditions. The preservation potential for such composite landscapes will to a large extent depend on the timing of any change in boundary conditions and the efficiency of surface processes.

[50] The boundary element modeling of fault interaction provides an approach to detect inherited landforms and help interpret the conditions under which they formed. Our methodology is a first-order, simplified abstraction that can provide guidance for further quantitative tectonic assessments of a region. In essence, our approach extends the use of landscapes as proxies for the degree of tectonic activity into regions that are far more complex compared to areas that have been studied in the past.

[51] This approach can be particularly beneficial in complex regions with faults of multiple orientations, areas that have experienced significant changes in the tectonic boundary conditions over time, areas with inherited structures, and even areas where changes in boundary conditions occurred several millions of years ago and hence may no longer contain clear signals of inherited topography within the fluvial network.

[52] Acknowledgments. This work was funded by the DFG Leibniz award to M. Strecker and a grant funded by the German Research Council (STR 373/19 - 1 to M. Strecker and A. Friedrich) and the German Academic Exchange Service (DAAD-D/07/42739). We wish to thank Birgit Fabian for her help with the drawings. We have benefited from discussions with G. Hilley, M. Trauth, F. Krüger, M. Ohrnberger, and S. Hainzl. We would like to thank S. Miller, B. Guest, S. Brocklehurst, G. Axen, A. Meigs, A. Densmore, an anonymous assistant editor, and an anonymous reviewer for their excellent reviews on this and an earlier version of this manuscript.

\section{References}

Allen, M. B., M. R. Ghassemi, M. Shahrabi, and M. Qorashi (2003), Accommodation of late Cenozoic oblique shortening in the Alborz range, northern Iran, J. Struct. Geol., 25, 659-672.

Allen, M. B., M. Kheirkhah, M. H. Emami, and St. J. Jones (2011), Rightlateral shear across Iran and kinematic change in the Arabia-Eurasia collision zone, Geophys. J. Int., 184, 555-574.

Ambraseys, N. N. (1974), Historical seismicity of north-central Iran. Material for the study of seismotectonics of Iran: North central Iran, Geol. Surv. of Iran, Rep., 29, 47-96, Tehran.

Ambraseys, N. N., and C. P. Melville (1982), A History of Persian Earthquakes, 219 pp., Cambridge Univ. Press, London.

Amini, B., and M. H. Emami (1993), Geological map of Iran, geological map, sheet Tehran, scale 1:100,000, Geol. Surv. of Iran, Tehran, Iran.

Anderson, R. S. (1990), Evolution of the northern Santa Cruz Mountains by advection of crust past a San Andreas Fault Bend, Science, 249 $397-401$

Anderson, R. S. (1994), Evolution of the Santa Cruz Mountains, California, through tectonic growth and geomorphic decay, J. Geophys. Res., 99, 20,161-20,179.

Anderson, R. S., and K. M. Menking (1995), The Quaternary marine terraces of Santa Cruz, California: Evidence for coseismic uplift on two faults, Geol. Soc. Am. Bull., 106, 649-664. 
Anderson, G., B. Aagaard, and K. Hudnut (2003), Fault interactions and large complex earthquakes in the Los Angeles area, Science, 302, 1946-1949.

Ashtari, M., D. Hatzfeld, and N. Kamalian (2005), Microseismicity in the region of Tehran, Tectonophysics, 395, 193-208.

Axen, G. J., P. S. Lam, M. Grove, and D. F. Stockli (2001), Exhumation of the west-central Alborz Mountains, Iran, Caspian subsidence, and collision-related tectonics, Geology, 29(6), 559-562.

Ballato, P., D. F. Stockli, M. Ghassemi, A. Landgraf, M. R. Strecker, J. Hassanzadeh, A. Friedrich, and S. H. Tabatabaei (2013), Accommodation of transpressional strain in the Arabia-Eurasia collision zone: New constraints from (U-Th)/He thermochronology in the Alborz Mountains, North Iran, Tectonics, 32, 1-18, doi:10.1029/2012TC003159.

Berberian, M., and R. S. Yeats (1999), Patterns of historical earthquake rupture in the Iranian Plateau, Bull. Seismol. Soc. Am., 89, 120-139.

Berberian, M., and R. S. Yeats (2001), Contribution of archeaological data to studies of earthquake history in the Iranian Plateau, J. Struct. Geol., 23, 563-584.

Bilham, R., and G. King (1989), The morphology of strike-slip faults: Examples from the San Andreas Fault, California, J. Geophys. Res., 94(B8), 10,204-10,216.

Bosworth, W., and M. R. Strecker (1997), Stress field changes in the AfroArabian rift system during the Miocene to Recent period, Tectonophysics, 278, 47-62.

Burbank, D. W., and N. Pinter (1999), Landscape evolution: The interactions of tectonics and surface processes, Basin Res., 11, 1-6.

Cooke, M. L., and A. Kameda (2002), Mechanical fault interaction within the Los Angeles Basin: A two-dimensional analysis using mechanical efficiency, J. Geophys. Res., 107(B7), 2146, doi:10.1029/2001JB000542.

Cortés, M., J. Angelier, and B. Colletta (2005), Paleostress evolution of the northern Andes (Eastern Cordillera of Colombia): Implications on plate kinematics of the South Caribbean region, Tectonics, 24, TC1008, doi:10.1029/2003TC001551.

Cowgill, E., A. Yin, J. R. Arrowsmith, X. F. Whang, and S. Zhang (2004), The Akato Tagh bend along the Altyn Tagh fault, northwest Tibet 1 : Smoothing by vertical axis rotation and the effect of topographic stresses on bend-flanking faults, Geol. Soc. Am. Bull., 116(11/12), 1423-1442, doi:10.1130/B25359.1.

Cowie, P. A., C. Vanneste, and D. Srnette (1993), Statistical physical model for the spatio-temporal evolution of faults, J. Geophys. Res., 98 , 21,809-21,821.

Cowie, P. A., S. Gupta, and N. H. Dawers (2000), Implications of fault array evolution for synrift depocentre development: Insights from a numerical fault growth model, Basin Res., 12, 241-261.

Crosby, B. T., K. X. Whipple, N. M. Gasparini, and C. W. Wobus (2007), Formation of fluvial hanging valleys: Theory and simulation, J. Geophys. Res., 112, F03S10, doi:10.1029/2006JF000566.

Dawers, N. H., M. Anders, and Ch. H. Scholz (1993), Growth of normal faults: Displacement-length scaling, Geology, 21, 1107-1110.

Dawers, N. H., and M. H. Anders (1995), Displacement-length scaling and fault linkage, J. Struct. Geol., 17(5), 607-614.

Densmore, A. L., M. A. Ellis, and R. S. Anderson (1998), Landsliding and the evolution of normal-fault-bounded mountains, J. Geophys. Res., 103(B7), 15,203-15,219.

Densmore, A. L., N. H. Dawers, S. Gupta, and R. Guidon (2005), What sets topographic relief in extensional footwalls?, Geology, 33(6) 453-456.

DiBiase, R. A., K. X. Whipple, A. M. Heimsath, and W. B. Oimet (2010), Landscape form and millennial erosion rates in the San Gabriel Mountains, CA, Earth Planet. Sci. Lett., 289, 134-144.

Ellis, M. A., and W. J. Dunlap (1988), Displacement variation along thrust faults: Implications for the development of large faults, J. Struct. Geol., 10(2), 183-192.

Ellis, M. A., and A. L. Densmore (2006), First-order topography over blind thrusts, in Tectonics, Climate, and Landscape Evolution, edited by $\mathrm{S}$. D. Willett et al., Penrose Conf. Ser., Spec. Pap. Geol. Soc. Am., 398, 251-266.

Garcia-Castellanos, D., and S. Cloetingh (2011), Modeling the interaction between lithospheric and surface processes in foreland basins, in Tectonics of Sedimentary Basins: Recent Advances, edited by C. Busby and A. Azor, Wiley-Blackwell, Chichester, West Sussex; Hoboken, NJ, 152-181. doi:10.1002/9781444347166.ch8

Gasparini, N. M., K. X. Whipple, and R. L. Bras (2007), Predictions of steady state and transient landscape morphology using sedimentflux-dependent river incision models, J. Geophys. Res., 112, F03S09, doi:10.1029/2006JF000567.

Golombek, M. P., G. E. McGill, and L. Brown (1983), Tectonic and geologic evolution of the Espanola Basin, Rio Grande Rift: Structure, rate of extension, and relation to the state of stress in the western United States, Tectonophysics, 94, 483-507.
Guest, B., G. J. Axen, P. S. Lam, and J. Hassanzadeh (2006a), Late Cenozoic shortening in the west-central Alborz Mountains, northern Iran, by combined conjugate strike-slip and thin-skinned deformation, Geosphere, 2, 35-52.

Guest, B., D. F. Stockli, M. Grove, G. J. Axen, P. S. Lam, and J. Hassanzadeh (2006b), Thermal histories from the central Alborz Mountains, northern Iran: Implications for the spatial and temporal distribution of deformation in northern Iran, Geol. Soc. Am. Bull., 118(11/12), $1507-1521$.

Grier, M. E., J. A. Salfity, and R. W. Allmendinger (1991), Andean reactivation of the Cretaceous Salta rift, northwestern Argentina, J. South Am. Earth Sci., 4(4), 351-372.

Haghipour, A., H. Taraz, and F. Vahdati Daneshmand (1987), Geological quadrangle map of Iran, no. F5, Tehran, 1:250000, Ministry of Mine and Metal; Geological Survey of Iran.

Hessami, K., and F. Jamali (2006), Explanatory notes to the map of major active faults of Iran, JSEE., $8(1), 1-11$.

Hetzel, R., M. Tao, S. Niedermann, M. R. Strecker, S. Ivy-Ochs, P. W. Kubik, and B. Gao (2004), Implications of the fault scaling law for the growth of topography: Mountain ranges in the broken foreland of north-east Tibet, Terra Nova, 16, 157-162.

Heidbach, O., M. Tingay, A. Barth, J. Reinecker, D. Kurfeß, and B. Müller (eds.) (2008), The world stress map-Release 2008, Commission for the Geological Map of the World, Paris, 1:46M.

Hilley, G. E., M. R. Strecker, and V. A. Ramos (2004), Growth and erosion of fold-and-thrust belts with an application to the Aconcagua fold-and-thrust belt, Argentina, J. Geophys. Res., 109, B01410, doi:10.1029/2002JB002282.

Hilley, G. E., P. M. Blisniuk, and M. R. Strecker (2005), Mechanics and erosion of basement-cored uplift provinces, J. Geophys. Res., 110, B12409, doi:10.1029/2005JB003704.

Hilley, G. E., and J. R. Arrowsmith (2008), Geomorphic response to uplift along the Dragon's Back pressure ridge, Carrizo Plain, California, Geology, 36, 367-370.

Hoke, G. D., B. L. Isacks, T. E. Jordan, N. Blanco, A. J. Tomlinson, and J. Ramezani (2007), Geomorphic evidence for post-10 Ma uplift of the western flank of the Central Andes $18^{\circ} 30^{\prime}-22^{\circ} \mathrm{S}$, Tectonics, 26, TC5021, doi:10.1029/2006TC002082.

Hongn, F., C. del Papa, J. Powell, I. Petrinovic, R. Mon, and V. Deraco (2007), Middle Eocene deformation and sedimentation in the PunaEastern Cordillera transition (23 degrees-26 degrees S); control by preexisting heterogeneities on the pattern of initial Andean shortening, Geology, 35(3), 271-274

Jackson, J., K. Priestley, M. Allen, and M. Berberian (2002), Active tectonics of the South Caspian Basin, Geophys. J. Int., 148 , 214-245.

King, G. C. P., R. Stein, and J. B. Rundle (1988), The growth of geological structures by repeated earthquakes 1: Conceptual framework, J. Geophys. Res., 93(11), 13,307-13,318.

Kirkup, St. (1998), The boundary element method in acoustics: A development in Fortran, ISBN 0953403106, $136 \mathrm{pg}$.

Landgraf, A., P. Ballato, M. R. Strecker, A. Friedrich, S. H. Tabatabaei, and M. Shahpasandzadeh (2009), Fault-kinematic and geomorphic observations along the North Tehran Thrust and Mosha-Fasham Fault, Alborz Mountains, Iran: Implications for fault-system evolution and interaction in a changing tectonic regime, Geophys. J. Int., 177, 676-690, doi:10.1111/j.1365-246X.2009.04089.x.

Lin, J., and R. Stein (2004), Stress triggering in thrust and subduction earthquakes and stress interaction between the southern San Andreas and nearby thrust and strike-slip faults, J. Geophys. Res., 109, 975-978, doi:10.1029/2003JB002607.

Manighetti, I., D. Zigone, M. Campillo, and F. Cotton (2009), Selfsimilarity of the largest-scale segmentation of the faults: Implications for earthquake behavior, Earth Planet. Sci. Lett., 288, 370-381.

Marrett, R. A., R. W. Allmendinger, R. N. Alonso, and R. E. Drake (1994), Late Cenozoic tectonic evolution of the Puna Plateau and adjacent foreland, northwestern Argentine Andes, J. South Am. Earth Sci., 7 , 179-207.

Marshak, St., K. Karlstrom, and J. M. Timmons (2000), Inversion of Proterozoic extensional faults: An explanation for the pattern of Laramide and Ancestral Rockies intracratonic deformation, United States, Geology, 28(8), 735-738.

Masson, F., M. Anvari, Y. Djamour, A. Walpersdorf, F. Tavakoli, M. Daignieres, H. Nankali, and S. Van Gorp (2007), Large-scale velocity field and strain tensor in Iran inferred from GPS measurements: New insight for the present-day deformation, Geophys. J. Int., 170, 436-440.

Meigs, A. J., M. L. Cooke, and S. T. Marshall (2008), Using vertical rockuplift patterns to constrain the three-dimensional fault configuration in the Los Angeles Basin, Bull. Seismol. Soc. Am., 98(2), 106-123. 


\section{LANDGRAF ET AL.: FAULT INTERACTION AND LANDSCAPE EVOLUTION}

Merritts, D., and M. Ellis (1994), Introduction to special section on tectonics and topography, J. Geophys. Res., 99(B6), 12,135-12,141.

Mora, A., M. Parra, M. R. Strecker, A. Kammer, C. Dimaté, and F. Rodríguez (2006), Cenozoic contractional reactivation of Mesozoic extensional structures in the Eastern Cordillera of Colombia, Tectonics, 25, TC2010, doi:10.1029/2005TC001854.

Okada, Y. (1992), Internal deformation due to shear and tensile faults in a half-space, Bull. Seismol. Soc. Am., 82, 1018-1040.

Power, W. L., and T. E. Tullis (1991), Euclidean and fractal models for the description of rock surface roughness, J. Geophys. Res., 96(B1), 415-424.

Priestley, K., C. Baker, and J. Jackson (1994), Implications of earthquake focal mechanism data for the active tectonics of the south Caspian Basin and surrounding regions, Geophys. J. Int., 118, $111-141$.

Renard, F., C. Voisin, D. Marsan, and J. Schmittbuhl (2006), High resolution 3D laser scanner measurements of a strike-slip fault quantify its morphological anisotropy at all scales, Geophys. Res. Lett., 33, L04305, doi:10.1029/2005GL025038.

Ritz, J.-F., H. Nazari, A. Ghassemi, R. Salamati, A. Shafei, S. Solaymani, and P. Vernant (2006), Active transtension inside Central Alborz: A new insight into the northern Iran-southern Caspian geodynamics, Geology, 34(6), 477-480.

Ritz, J.-F., H. Nazari, S. Balescu, M. Lamothe, R. Salamati, A. Ghassemi, A. Shafei, M. Ghorashi, and A. Saidi (2012), Paleoearthquakes of the past 30,000 years along the North Tehran Fault (Iran), J. Geophys. Res., 117, B06305, doi:10.1029/2012JB009147.

Ron, H., A. Nur, and A. Aydin (1993), Stress field rotation or block rotation: An example from the Lake Mead fault system, Annali di Geofisika, $X X X V I(2), 65-73$

Sagy, A., E. E. Brodsky, and G. J. Axen (2007), Evolution of fault-surface roughness with slip, Geology, 35(3), 283-286.

Schildgen, T. F., D. Cosentino, B. Bookhagen, S. Niedermann, C. Yildirim, H. A. Echtler, H. Wittmann, and M. R. Strecker (2012), Multi-phase uplift of the southern margin of the Central Anatolian plateau: A record of tectonic and upper mantle processes, Earth Planet. Sci. Lett., 317-318, 85-95, doi:10.1016/j.eps1.2011.12.003.

Scholz, C. H. (1982), Scaling laws for large earthquakes: Consequences for physical models, Bull. Seismol. Soc. Am., 72(1), 1-14.

Scholz, C. H. (2002), The Mechanics of Earthquakes and Faulting, 2nd ed., 471 pp., Cambridge Univ. Press, Cambridge, U. K.

Schumacher, M. E. (2002), Upper Rhine Graben: Role of preexisting structures during rift evolution, Tectonics, 21(1), 1006, doi:10.1029/ 2001 TC900022.

Spotila, J. A. (2012), Influence of drainage divide structure on the distribution of mountain peaks, Geology, 40(9), 855-858.

Stein, R., G. C. P. King, and J. B. Rundle (1988), The growth of geological structures by repeated earthquakes 2 : Field examples of continental dipslip faults, J. Geophys. Res., 93(11), 13,319-13,331.

Stein, R. S., A. A. Barka, and J. H. Dieterich (1997), Progressive failure on the North Anatolian fault since 1939 by earthquake stress triggering, Geophys. J. Int., 128, 594-604.

Strecker, M. R., P. Blisniuk, and G. H. Eisbacher (1990), Rotation of extension direction in the central Kenya Rift, Geology, 18, 299-302.

Strecker, M. R., and R. Marrett (1999), Kinematic evolution of fault ramps and its role in development of landslides and lakes in the northwestern Argentine Andes, Geology, 27(4), 307-310.

Taboada, A., J. C. Bousquet, and H. Philip (1993), Coseismic elastic models of folds above blind thrusts in the Betic Cordilleras (Spain) and evaluation of seismic hazard, Tectonophysics, 220, 223-241.

Tatar, M., J. Jackson, D. Hatzfeld, and E. Bergman (2007), The 2004 May 28 Baladeh earthquake (Mw 6.2) in the Alborz, Iran: Overthrusting the South Caspian Basin margin, partitioning of oblique convergence and the seismic hazard of Tehran, Geophys. J. Int., 170, 249-261.
Toda, S., R. S. Stein, Sevilgen V., and L. Lin (2011), Coulomb 3.3 Graphicrich deformation and stress-change software for earthquake, tectonic, and volcano research and teaching-user guide, U.S. Geological Survey Open-File Report 2011-1060, 63 pp.

Tomkin, J. H., and G. H. Roe (2007), Climate and tectonic controls on glaciated critical-taper orogens, Earth Planet. Sci. Lett., 262(3-4), 385-397.

Trauth, M. (2007), MATLAB® Recipes for Earth Sciences, 2nd ed., 288 pp., Springer Verlag, Berlin, Heidelberg.

Tucker, G. E., and R. Slingerland (1996), Predicting sediment flux from fold and thrust belts, Basin Res., 8, 329-349.

Vahdati, D. (1997), Geological map east of Tehran quadrangle: Geological survey of Iran, scale 1:100 000, 1 sheet.

Vernant, P. et al. (2004a), Present-day crustal deformation and plate kinematics in the Middle East constrained by GPS measurements in Iran and northern Oman, Geophys. J. Int., 157, 381-398.

Vernant, P., F. Nilforoushan, J. Chery, R. Bayer, Y. Djamour, F. Masson, H. Nankali, J. F. Ritz, M. Sedighi, and F. Tavakoli (2004b), Deciphering oblique shortening of central Alborz in Iran using geodetic data, Earth Planet. Sci. Lett., 223, 177-185.

Walsh, J. J., A. Nicol, and C. Childs (2002), An alternative model for the growth of faults, J. Struct. Geol., 24, 1669-1675.

Whipple, K. X., E. Kirby, and S. H. Brocklehurst (1999), Geomorphic limits to climate-induced increases in topographic relief, Nature, 401, 39-43.

Whipple, K. X., and G. E. Tucker (1999), Dynamics of the stream-power river incision model: Implications for height limits of mountain ranges, landscape response timescales, and research needed, J. Geophys. Res., 104(B8), 17,661-17,674.

Whipple, K. X., G. S. Hancock, and R. S. Anderson (2000), River incision into bedrock: Mechanics and relative efficacy of plucking, abrasion, and cavitation, Bull. Seismol. Soc. Am., 112(3), 490-503.

Whipple, K. X. (2001), Fluvial landscape response time: How plausible is steady-state denudation?, Am. J. Sci., 301, 313-325.

Whipple, K. X. (2009), The influence of climate on the tectonic evolution of mountain belts, Nat. Geosci., 2(2), 97-104.

Whittaker, A. C. (2012), How do landscapes record tectonics and climate?, Lithosphere, 4, 160-164.

Willett, S. D., and M. T. Brandon (2002), On steady states in mountain belt, Geology, 30, 175-178.

Wobus, C., K. X. Whipple, E. Kirby, N. Snyder, J. Johnson, K. Spyropolou, B. Crosby, and D. Sheehan (2006), Tectonics from topography: Procedures, promise, and pitfalls, in Tectonics, Climate, and Landscape Evolution, edited by S. D. Willett et al., Penrose Conf. Ser., Spec. Pap. Geol. Soc. Am., 398, 56-75.

Yildirim, C., T. F. Schildgen, H. Echtler, D. Melnick, and M. R. Strecker (2011), Late Neogene and active orogenic uplift in the Central Pontides associated with the North Anatolian Fault: Implications for the northern margin of the Central Anatolian Plateau, Turkey, Tectonics, 30, TC5005, doi:10.1029/2010TC002756.

Zanchi, A., F. Berra, M. Mattei, M. R. Ghassemi, and J. Sabouri (2006), Inversion tectonics in central Alborz, Iran, J. Struct. Geol., 28(11), 2023-2037.

Zielke, O., and R.-J. Arrowsmith (2006), Numerical simulation of fault interaction in a trans-tensional setting, the La Paz Los Cabos Region, Baja California, Mexico, Eos Trans. $A G U$, 87(52), Fall Meet. Suppl., Abstract T41D-1613.

Zielke, O., and R.-J. Arrowsmith (2007), Empirical relationships among magnitude and surface rupture characteristics of strike-slip faults: Effect of fault (system) geometry and observation location, derived from numerical modeling, Eos Trans. $A G U, 88(52)$, Fall Meet. Suppl., Abstract T33C-1488.

Zielke, O. (2009), How fault geometric complexity and frictional properties affect seismic fault behavior and accumulation of slip along strike-slip faults, PhD thesis, Arizona State University, 330 pp., 3391813. 